\title{
JUDICIAL INTERVENTION IN CHURCH PROPERTY DISPUTES - SOME CONSTITUTIONAL CONSIDERATIONS
}

EVERx year, a number ${ }^{1}$ of church property disputes come before the civil courts. These controversies arise from schisms, political quarrels within churches, unions or mergers between churches, appointment of clergy, and expulsion of members. Each of these disputes will, in the end, touch upon questions of right to use or right to prescribe use of church property. Traditionally states have been interested in settling these quarrels because of their desire to have title and ownership of land settled and secure. Hovever, courts have always been wary of becoming embroiled in these church property disputes. Until recently, this reluctance stemmed more from the belief that church and state should be separate than from any specific dictates of the establishment or free exercise clauses of the first amendment. In 1952 the Supreme Court, in the landmark decision of St. Nicholas Cathedral v. Kedroff, 2 introduced new constitutional dimensions into this area of the law. Although the litigation dragged on until 1960 , the various problems raised by the decision in Kedroff have yet to be successfully resolved. Among these problems are: What criteria of ownership are relevant to settlement of church property disputes? How can courts avoid involvement in theological controversies and at the same time successfully deal with property disputes? To what extent do the constitutional guarantee of freedom of exercise of religion and its correlative prohibition of an establishment of religion impinge upon the various methods courts can use to settle these disputes? Because these questions have been raised and not answered, an area of law which was relatively clear and settled before $K e d r o f f$ has become shrouded in uncertainty.

An examination of the development and growth of the prior law may illuminate the considerations involved in arriving at a coherent body of rules for settling church property disputes. The first formulation of an uniquely American doctrine was announced by Mr. Justice Miller in 1871, in the celebrated case of Watson $v$. Jones. ${ }^{8}$ The question of slavery had deeply divided the Presbyterian Church. During the Civil War, the highest church authorities had supported the Northem cause. Immediately after the war, the General Assembly $^{4}$ issued instructions to the inferior governing bodies that applicants for

1. About ten cases per year from the federal courts and the highest state courts appear in the digests.

2. St. Nicholas Cathedral v. Fedchenkoff, 192 Misc. 327, 77 N.Y.S.2d 333 (Sup. Ct. 1948), affd sub nom. St. Nicholas Cathedral v. Kedroff, 276 App. Div. 309, 94 N.Y.S.2d 453 (1950), rev'd, 302 N.Y. 1, 96 N.E.2d 56 (1950), rej'd and remanded, 344 U.S. 94 (1952), new trial ordered, 306 N.Y. 38, 114 N.E.2d 197 (1953), dismissed sub nom. St. Nicholas Cathedral v. Kreshik, 9 Misc. 2d 1069, 166 N.Y.S.2d 245 (1957), affirmed 6 App. Div. $2 d$ 866, 176 N.Y.S.2d 226 (1958), redd, 7 N.Y.2d 191, 164 N.E.2d 687 (1959), redd per curiam, 363 U.S. 190 (1960).

3. 80 U.S. (13 Wall.) 679 (1871).

4. The governing system of the Presbyterian Church is divided into four levels. At the lower end are the Sessions, consisting of the Pastor and elected elders of a particular congregation. The next higher body is the Presbytery, consisting of all ministers and one 
church membership, missionary posts or pastoral positions who had aided the Southern cause or had agreed with the dogma of the schismatic Southern Church that slavery was a "divine institution" should be required to "repent and forsake these sins" before they could be received." These instructions produced wide dissension in the Kentucky church, particularly within the congregation of the Walnut Street Church. The majority of the church members was of the anti-slavery group, but the dissenters controlled the apparatus of the parish government. The dispute between the two factions soon centered on control of property used by the Walnut Street congregation. The Kentuclky courts ruled for the pro-slavery minority, holding that a decision of the General Assembly in favor of the majority was ultra vires under the church constitution. ${ }^{6}$ After this setback in the state court, the anti-slavery group mannged to get the case into the federal courts on diversity grounds. ${ }^{\top}$ The circuit court ruled that the anti-slavery group had the right to the church property. The Supreme Court affirmed on the ground that the anti-slavery faction alone had been recognized by the General Assembly, the highest church authority.

In searching for a rationale, Justice Miller was faced with a paucity of federal precedent ${ }^{8}$ and a divergence of opinion in the state courts. ${ }^{0}$ There was,

ruling elder from each congregation within a district. Next is the Synod, made up of all ministers and one ruling elder from each congregation in a larger district. The supremo authority is vested in the General Assembly, made up of ministers and elders commissioncd from each Presbytery. In Watson v. Jones, the chain of command involved the (nationwide) General Assembly, the Kentucky Synod, the Louisville Presbytery, and the Session, board of trustees and congregation of the Walnut Street Presbyterian Church in Louisville. Id. at 727.

5. Id. at 691.

6. Watson v. Avery, $65 \mathrm{Ky}$. (2 Bush) 332 (1867). The church constitution was interpreted very narrowly, because the court felt that to allow the General Assembly to determine its own jurisdiction would substitute the whim of the Assembly for the written constitution as the law of the church. "[T]he constitution having been adopted as the supreme law of the church, [it] must be supreme alike over the assembly and people." Id. at 349. The Kentucky court went so far as to draw analogies between the church and federal Constitutions to show that the General Assembly had exceeded its authority. Id. at 357-59. However, this court may have been itself subject to ambivalent feelings on the slavery question. A year later, in Gartin v. Penick, $68 \mathrm{Ky}$. (5 Bush) 110 (1868), the same court in a similar case declared that "... President Lincoln's proclamation of emancipation had aggravated the horrors of the war, and perverted it from a defense of the Union into a military crusade against slavery. ..."Id. at 129. Again this court found that the General Assembly had exceeded their authority in requiring the loyalty oath and the renouncing of slavery as a condition of membership in the Presbyterian Church.

7. The case was brought by three parishioners who lived across the Ohio River in Indiana. 80 U.S. (13 Wall.) at 694 (1871).

8. Church property disputes were only allowed into federal courts on grounds of diversity. No federal question was thought to be raised, principally because the fourteenth amendment was only a few years old, and the courts were not yet ready to cnforce first amendment guarantees through the fourteenth amendment. See Cantwell v. Connecticut, 310 U.S. 296 (1940) for a history of the incorporation of the first amendment in religious liberty cases.

9. The New England courts leaned toward a doctrine of congressional autonomy, while elsewhere the courts favored an implied trust theory. Under the New England doctrinc, 
however, a clear body of English doctrine holding that church property was the subject of an implied trust in favor of those who adhered to the faith of the founders of the church. This doctrine was first fully articulated in an 1817 case, Attorney General v. Pearson, ${ }^{10}$ in which a congregation had become distressed when their minister, after preaching the Unitarian doctrine for three years, suddenly switched to Trinitarianism. Lord Chancellor Eldon, announcing the opinion of the court, said:

[W] here a congregation has become dissentient among themselves, the nature of the original institution must alone be looked to ... and ... to refer to any other criterion - as to the sense of the existing majority would be to make a new institution, which is altogether beyond the reach, and inconsistent with the duties and character, of this court. ${ }^{11}$

Lord Eldon provided these criteria to determine "the nature of the original institution":

[When] it cannot be discovered from the deed declaring the trust what form or species of religious worship was intended, the Court [can inquire] into what has been the usage of the congregation in respect to it; and ... [it is] the duty of the Court to administer the trust in such a manner as best to establish the usage, considering it as a matter of implied contract between the members of the congregation. ${ }^{12}$

The opinion made it clear, however, that it would be rare for a court to be unable to determine what form of worship was intended by the trust deed. ${ }^{13}$ The English doctrine thus froze the property use within a church to the faith of the founders of that church. ${ }^{14}$

the congregation was the basic church entity, no matter what form of Church government the mother Church might espouse. The implied trust doctrine of the Southern, Western and Middle Atlantic states in essence held that the church property was impressed with a trust for the maintenance of the forms of ecclesiastical government set up by the founders. See Note, Judicial Intervention in Disputes Over the Use of Church Properly, 75 Hans. L. Rev. 1142, 1149-54 (1962) and cases cited.

10. 3 Mer. 353, 36 Eng. Rep. 135 (Ch. 1817). Also see Craigdallie v. Aikman, 1 Dow 1, 3 Eng. Rep. 601 (H.L. 1813) (Scot.), also decided by Lord Eldon.

11. 3 Mer. 400-01, 36 Eng. Rep. at 150.

12. Ibid.

13. In the instant case, Lord Eldon made a searching examination of the Toleration Act ( 1 W. \& M. c. 18) by which he presumed to show that since Unitarianism remained illegal after this Act, it was highly likely that the original founders espoused some form of Trinitarianism, even though the church trust-deed did not so specify. The case was finally sent to a Master for adjudication of the issues involved, including the question of original doctrine. 3 Mer. 419-20, 36 Eng. Rep. 157.

14. In Attorney General v. Pearson, note 10 stipra, the court construed a deed to a single church building. It was not forced to decide whether the "faith of the founders" of an entire church was to be measured at the time of donation of property or at the original founding of the parent church. The logical result of the latter rule would be that a minority, however small, could force a majority of an entire church to conform to the doctrines of the founders or relinquish the church property. This actually happened in 1904 when the House of Lords held that all the properties of the Free Church of Scotland should be awarded to a miniscule minority having less than 30 clergymen. Free Church of Scothand v. Lord Overtoun, [1904] A.C. 515 (Scot.). Parliament reversed this decision the next 
In Watson v. Jones Justice Miller rejected the English doctrine and attempted to develop a new set of rules designed to cover all church property disputes. The first of his three rules recognized applicability of the trust theory only in the situation where the trust deed prescribed some specific form of religious doctrine or belief, and where any members of the present congregation who adhered to the specified doctrine wished to use the property. ${ }^{15}$ Mr. Justice Miller felt that there were strong reasons for refusing to follow the English trust theory in situations in which the deed of trust did not specify the religious doctrine to be followed. The English rule would require revicw of decisions of church authorities by civil courts - "an appeal from the more learned tribunal in the law which should decide the case, to one which is less so."18 Another reason for limiting the English rule was to insure adherence to the peculiarly American policy of separation of Church and State. Mr. Justice Miller postulated that religious freedom included:

The right to organize voluntary religious associations .... and to create tribunals for the decision of controverted questions of faith within the association, and for the ecclesiastical government of . . . members, congregations and officers. ... .17

Those who unite themselves in such religious organizations "do so with implied consent to this government, and are bound to submit to it."18 Therefore, if secular courts could reverse a church decision and allow a dissatisfied member to revoke his original consent, the mutual consent of all the members would be vain and the courts' action would lead to "the total subversion of stich religious bodies. ..."10 From these assumptions, Mr. Justice Miller concluded that true separation of church and state could be achieved only by treating church decisions as final. ${ }^{20}$ In this way, civil courts could remain aloof from theological year, allowing the majority to regain control of the property -800 churches, three universities and more than $£ 1,000,000$ of invested funds. Churches (Scotland) Act, 1905, 5 Edw. 7, c. 12. See also Epaphroditus Peck, American Versus British Ecclesiastical Lazu, 15 YALE L.J. 255 (1906).

15. [W] hen the property ... has been, by deed or will of the donor ... by the express terms of the instrument devoted to the teaching, support, or spread of some specific form of religious doctrine or belief .... it would seem ... the obvious duty of the court ... to see that the property so dedicated is not diverted from the trust.... So long as there are persons qualified within the meaning of the original dedication ... and so long as there is anyone so interested in the execution of the trust as to have a standing in court, it must be that they can prevent the diversion of the property or fund to other and different uses.

80 U.S. (13 Wall.) at 722-23.

16. Id. at 729 .

17. Ibid.

18. Ibid.

19. Ibid.

20. It is of the essence of these religious unions, and of their right to establish tribunals for the decision of questions arising among themselves that those decisions should be binding in all cases of ecclesiastical cognizance, subject only to such appeals as the organism itself provides for.

Ibid. 
disputes. ${ }^{21}$ In addition, according finality to the decisions of church authorities, rather than testing church doctrine against the beliefs of the founders, would allow natural growth and change in the doctrines of the church.

Justice Miller next concentrated on a search for the proper decision-making body within a church. He saw a fundamental distinction between the government consented to by the members of congregational churches and that consented to by members of hierarchical churches. In a congregational church the members consent to abide either by the will of the majority or by the decisions of the elected elders. In a hierarchical church, the "whole body" speaks through the highest church authority. The second and third rules of Watson v. Jones, therefore, to be applied in the absence of specific trust provisions, encompassed the forms of ownership of property in congregational and hierarchical churches. In a church which is, as to property matters, "governed solely within itself," the court would enforce the decision of the majority or the elected elders; $;$ in churches where the "religious congregation ... holding the property is but a subordinate member of some general church," the civil courts would defer to the decisions of the highest authority of the general church. ${ }^{23}$

21. Mr. Justice Miller emphasized that even the church determination of its own jurisdiction was to be accorded finality:

- There is, perhaps, no word in legal terminology so frequently used as the word jurisdiction, so capable of use in a general and vague sense, and which is used so often by men learned in the law without due regard to precision in its application.... [I]t is easy to see that if civil courts are to inquire into all these matters, the whole subject of the doctrinal theology, the usages and customs, the written laws, and fundamental organization of any religious denomination may, and must, be examined into with minuteness and care, for they could become, in almost every - case, the criteria by which the validity of the ecclesiastical decree would be determined in the civil court. This principle would deprive these bodies of the right of construing their own church laws, [and] $\ldots$ open the way to the ... [English] evils. $\therefore$

Id. at 732-33.

22. In the case of property held by a religious congregation

governed solely within itself, either by a majority of its members or by such other local organism as it may have instituted for the purpose of ecclesiastical government .... the rights ... to [such] property (in case of schism) must be determined by the ordinary principles which govern voluntary associations. . . . This ruling admits of no inquiry into the existing religious opinions of those who comprise the legal or regular organization: for, if such was permitted, a very small minority ... might be found to be the only faithful supporters of the religious dogmas of the founders of the church. There being no such trust imposed upon the property when purchased or given, the court will not imply for the purpose of expelling from its use those who by regular succession and order constitute the church, because they may have changed in some respect their views of religious truth.

Id. at 722, 724-25.

23. [W] but a subordinate member of some general church organization in which there are superior ecclesiastical tribunals with a general and ultimate power of control more or less complete, in some supreme adjudicatory over the whole membership of that general organization ... [w] henever the questions of discipline or of faith or 
In applying his rules to the case at hand, Miller began by dismissing as irrelevant the fact that title to the Walnut Street property resided in the board of trustees, since they were not significant in the scheme of church government but simply held the land for the use and benefit of the congregation - the true body of the church - who alone had the rights of user in the building. ${ }^{24}$ This "true body" was to be defined in cases of dispute by the General Assembly," the highest church authority. Thus that portion of the congregation recognized by the General Assembly was entitled to use and enjoyment of the church property.

There will be times, however, when finding the authoritative tribunal within a church will not resolve the dispute. The task of determining the extent of that tribunal's power over church members may still remain. Watson $v$. Jone's assumes that power to be plenary. Many courts since that decision, however, though recognizing its status as a leading case, have been unwilling to recognize such unlimited power in the hands of church authorities. The policy of complete deference to church tribunals was quickly eroded as the courts began to realize that the consent of an individual member to be governed may not have been unconditional. The courts began to demand from the church tribunals adherence to some rudimentary notions of fairness. This erosion began in Bouldin v. Alexander ${ }^{20}$ with an implication that the court would only defer to a church tribunal which had followed its own procedural rules. In that case, the Supreme Court, in holding that the minority of a congregational church could not subvert the will of the majority, said: "In a congregational church, the majority, if they adhere to the organization and the doctrines, represent the church." 27 The requirement of procedural regularity modifies the doctrine of Watson $v$. Jones by imposing traditional notions of fairness on the church tribunals.

Beginning with the limitations expressed in Bouldin v. Alexander, the federal courts since Watson $v$. Jones have examined church decisions, sometimes rather closely, to ensure that these decisions have been fair and just to disputing church members, within the context of church doctrine and procedures. Brundage v. Deardroff, ${ }^{28}$ for example, involved a dispute between two factions

ecclesiastical rule, custom, or law have been decided by the highest of these church judicatories to which the matter has been carried, the legal tribunals must accept such decisions as final, and as binding upon them, in their application to the case before them.

Id. at $722,727$.

24. The trustees of the church had no power to control use of the property, since they held possession for the true body of the church, the "persons who by the constitution, usages and laws of the Presbyterian body, are entitled to that use." 80 U.S. (13 Wall.) at 720 .

25. Id. at 726-27.

26. 82 U.S. (15 Wall.) 131 (1872).

27. Id. at 140. (Emphasis added.)

28. 55 F. 839 (C.C.N.D. Ohio 1893). The case in the district court was heard on at demurrer on grounds that the minority party plaintiffs had a remedy at law by ejection rather than in equity. This demurrer was overruled. $I d$. at 842 . 
of the Church of United Brethren of Christ, a national hierarchical church, concerning a new declaration of faith and a new constitution which had been adopted by a majority vote at a regularly held church convention. Both warring factions claimed that the other had seceded, and each faction had established its own hierarchy, which it claimed to be the true governing authority of the church. After distinguishing Watson v. Jones on factual grounds, Judge Taft interpreted that case as laying down the proposition that

only a bona fide decision [by a church tribunal] of the fundamental law of the church must be recognized as conclusive by civil courts. Clearly, it was not the intention of the court to recognize as legitimate the revolutionary action of a majority of the supreme judicatory, in fraud of the rights of a minority seeking to maintain the integrity of the original compact. ${ }^{2 \theta}$

The new constitution and the procedures followed in ratifying it were then examined at length, and the court held that a vote of 50,000 for amendment of a total of 204,000 church members did not satisfy the church constitutional requirement of a two-thirds vote, that the amendment was void, and that therefore the minority group which adhered to the old constitution was entitled to the property. ${ }^{30}$

The court of appeals, in reaching the opposite result, ${ }^{31}$ did not question the propriety of Judge Taft's examination of the fairness of the church tribunal's action, but after a detailed examination of the church doctrine, decided that the church conference had the power to amend the church constitution, and also to rule on the procedures for amendment. Apparently the 50,000 votes were the most ever polled in a United Brethren election, and proper notice had been given to all concerned. The court found, therefore, that the election procedure was proper and that the requirements of the church constitution had been satisfied. $^{32}$

The modification of Watson $v$. Jones by later case law is best summarized in Mr. Justice Brandeis' restatement of the Watson rule in Gonzalez v. Archbishop. ${ }^{33}$ Though the holding followed Justice Miller's opinion in giving effect to the ruling of the highest church authority, the statement of the rule the

29. Id. at $847-48$.

30. Id. at 849 .

31. 92 F. 214 (6th Cir. 1899).

32. Other courts have also inquired into the procedural aspects of clurch decisions. See, e.g., Evangelical Lutheran Synod v. First English Lutheran Church, 47 F. Supp. 954 (W.D. Okla. 1942), rev'd, 135 F.2d 701 (10th Cir. 1943); Barkley v. Hayes, 208 Fed. 319 (W.D. Mo. 1913), aff'd sub nom. Duvall v. Synod of Kansas, 222 Fed. 669 (8th Cir. 1915), aff'd sub nom. Shepard v. Barkley, 247 U.S. 1 (1918).

33. 280 U.S. 1 (1929). The decision of church authorities was allowed to stand in denying a chaplaincy to a boy of 14 who had taken no religious vows. The chaplaincy had been established by the boy's ancestor, and it was provided that the claplaincy would remain in the family as long as someone was qualified. The boy's theory was that he could receive the money from the chaplaincy fund, and use part of it to have the requisite masses said by a priest. The Archbishop of the diocese refused to approve this arrangement, and was upheld by the civil courts. 
courts were to apply in church disputes significantly expanded Miller's original formulation:

In absence of fraud, collusion or arbitrariness, the decisions of the proper church tribunals on matters purely ecclesiastical, although affecting civil rights, are accepted in litigation before the secular courts as conclusive, because the parties in interest made them so by contract or otherwise. ${ }^{34}$

Under this rule the role of the civil court includes an examination of the fairness of the church proceedings both to determine the good faith of the church authorities ("absence of fraud, collusion") and also to determine whether the church tribunal has blatantly disregarded its own rules ("or arbitrariness"). In sum, the line of cases culminating in Gonzalez v. Archbishop diluted the Watson principle of absolute deference to church authorities. Implicit in these cases was the concept that the consent of the members to be governed by the church authorities did not envision fraudulent, arbitrary, or collusive action by these authorities. ${ }^{35}$ This is not to say that church rules and doctrine, though seemingly arbitrary or unfair in the eyes of the outsiders, should not be enforced, but that the church and the member are bound by existing rules. These rules can, of course, be changed in accordance with the church's procedure for altering such rules, and in determining the validity of such change, civil courts once again should give heavy weight to the findings of the church tribunals. ${ }^{\text {Do }}$

While the rules of Watson $v$. Jones were being modified to embody a concept of fairness, courts continued to overlook a conceptual difficulty within the

34. Id. at 16.

35. A further caveat, of course, is recognized when the doctrines of a church run directly counter to state policy. The usual finding of a civil court will be that such an organization is not really religious in nature, and thus not entitled to the deference prescribed in Watson v. Jones. Hansel v. Purnell, 1 F.2d 266 (6th Cir. 1924), illustrates the considerations involved in determining whether or not a church authority is barred by public policy from exercising control over the property rights of a member. Hansel sued the founders of the "Israelite House of David," a community organized for supposedly religious purposes, to have property reconveyed which he had deeded to the church on joining.

The court interpreted the rule of Watson $v$. Jones as follows:

If the religious doctrines promulgated by [the founder] and accepted by the Israclite House of David violate no law or rule of public policy, the courts have no power to interfere with the practice or the teachings of that faith, or afford any relief to one who voluntarily withdraws or has been rightfully expelled for the causes namcd and in the manner provided by the laws or rules or regulations of the society.

Id. at 270. The court held that the "House of David" failed at the first test. The organization was found to be not religious, but only a cloak to allow the founder to induge in his proclivity of seducing the women of the group under "religious" pretexts. Clashes between public policy and religious practice have involved inter alia plural marriages, Reynolds v. United States, 98 U.S. 145 (1879); Davis v. Beason, 133 U.S. 333 (1890); The Late Corp. of the Church of Jesus Christ of Latter-day Saints v. United States, 136 U.S. 1 (1890); and use of religion in a conspiracy to use the mails to defrautd, United States v. Ballard, 322 U.S. 78 (1944).

36. For an example of this deference, see the opinion of the court of appeals in Brundage v. Deardorf, 92 F. 214 (6th Cir. 1899). 
rule encompassing hierarchical churches. Mr. Justice Miller never defined clearly the way a hierarchical church "owns" or "holds" property. In most hierarchical churches, the church authorities do not hold property in fee simple; rather ownership is a more complex bundle of discrete rights, distributed among various members of the church. Three major attributes of ownership may be isolated - formal title, right to beneficial use, and right to prescribe use. Mr. Justice Miller correctly recognized that the location of formal title was meaningless for the purposes of resolving property disputes. He further realized that though the right of beneficial use might lie in a congregation, this attribute was not dispositive. Instead of concentrating upon the right to prescribe use, however, Mr. Justice Miller focused on the right to define membership, apparently assuming that the latter encompassed the former. Although this assumption may be valid in the great majority of cases, it diverts attention from what should be crucial in disputes over church property - which body within the church has the right to prescribe beneficial use. In those cases in which the church organization is such that the right to prescribe use is not coterminus with the right to define membership, the misleading focus of $W$ atson $v$. Jones may produce a result unwarranted by the actual church rules.

Master v. Second Parish of Portland ${ }^{37}$ illustrates the danger of mechanical application of $W$ atson $v$. Jones. The case involved a merger between a Congregational and a Presbyterian church. The Presbyterians sold their church and moved into the Congregational Church. The proceeds of the sale were applied to the debts of the two merging churches and the balance was held for the united congregation. The new organization hired a Presbyterian pastor and practiced the Presbyterian faith. The articles of union provided that in case of dissolution of the united church, the property was to be apportioned according to the present valuation and contributions of each merging group. ${ }^{\text {BS }}$ Subsequently a nation-wide schism occurred in the Presbyterian Church, and the congregation voted 76 to 1 to secede from the Presbyterian Church and join a newly formed body called the Orthodox Presbyterian Church of America. The Presbyterian Synod of Newburyport refused to allow the congregation to secede, and the ensuing quarrel over the church property was brought before the federal courts.

The district court framed the issue correctly:

It is not a question as to which of two parties in a Presbyterian church shall have possession of Presbyterian property. ... The question is, to what extent did the agreement [to merge] make [the Congregational church] Presbyterian property and subject to Presbyterian judicatory control? ? $^{39}$

However, the district court did not find it necessary to proceed to the question of what property rights the congregation had surrendered to the Presbyterian authorities. Instead, it chose to apply Article I, Section 3, of the Maine

\footnotetext{
37. 36 F. Supp. 918 (D. Me. 1940), affd, 124 F.2d 622 (1st Cir. 1941).

38. 124 F.2d at 625 .

39. 36 F. Supp. at 926 .
} 
Constitution, which it interpreted as imposing a congregational form of church government on all churches within the State, regardless of the actual church polity. ${ }^{40}$

The court of appeals, per Judge Magruder, in affirming the district court, neatly sidestepped the question of whether the state constitution was applicable, and disposed of the case on the ground that the Presbyterian hierarchy had never acquired the right to prescribe tuse of the property. In support of this conclusion he pointed out that the trustees of the former Presbyterian Church had ceased to function after the merger, the property of the merged congregation being administered by the trustees of the former Congregational Church, and further that the articles of merger provided for division of the property in the event of dissolution of the merged church. Judge Magruder admitted that the old Portland Presbyterian Church had been under the control of the national Presbyterian Church hierarchy. However, he reasoned that the merger agreement gave the new congregation only the right to use and occupy the church by license of the old Congregational congregation, which did not surrender enough of its autonomy to transfer control of the church building to the Presbyterian hierarchy.11 If the court of appeals in Master had applied the rule of Watson v. Jones literally, merely looking to the decision of that body having the right to prescribe membership, it would have been forced to defer to the decision of the Presbyterian hierarchy. Master thus illustrates that the Watson v. Jones assumption that the right to prescribe use is always found in the church hierarchy is an overgeneralization. Courts must therefore be particularly careful to identify in each case the location of the right to prescribe use of the property in question.

By 1950 , the principles of Watson $v$. Jones, modified to minimize arbitrary action by church tribunals, though not of constitutional status, were widely followed by state and federal courts. ${ }^{42}$ The Master case had recognized the

40. The relevant section reads as follows:

[A]11 religious societies in this state, whether incorporate or unincorporate, shall at all times have the exclusive right of electing their public teachers and contracting with them for their support and maintenance. ME. Const. art. $1, \S 3$.

41. Whether the Presbyterian hierarchy was entitled to the surplus of the procceds of the sale of the old Presbyterian church after debts had been paid, or reimbursement for funds paid from these proceeds to settle the debts of the Congregational church, was not decided.

42. Sims v. Greene, 160 F.2d 512 (3d Cir. 1947), illustrates. The case involved an argument between two ministers, each claiming to be the Bishop of Philadelphia, African Methodist Episcopal Church. The district court issued a temporary restraining order to the plaintiff, but the court of appeals reversed and directed the district court to proceed to a hearing on the merits. In laying down guidelines for the court below to follow, the following propositions were advanced:

a) Pennsylvania law, under Erie, must be applied.

b) Pennsylvania law requires inquiry as to the applicable church law, a detcrmination whether the church law has been followed by church tribunals, and enforcement of the church order if it has been reached legally.

The district court in deciding the case, 76 F. Supp. 669 (E.D. Pa. 1947), investigated the church law very thoroughly, and was able to avoid the theological questions in deciding 
major conceptual difficulty inherent in Watson $v$. Jones and had pointed the way to its resolution. Thus the doctrine for resolving property disputes within churches had become relatively clear, and courts apparently had little difficulty in applying it. This calm was rudely shattered in 1952 by the Supreme Court opinion in Kedroff $v$. St. Nicholas Cathedral.43 The Kedroff opinion purported to raise Watson $v$. Jones to constitutional status, and thereby injected the first amendment issues of establishment and freedom of exercise into every case involving a dispute over church property. However, in Kedroff, the Supreme Court failed to realize that the application of Watson $v$. Jones might itself be viewed as violating the constitutional prohibitions against establishment of or denial of free exercise of religion. This inconsistency within the Kedroff opinion has thrown the law surrounding church property disputes into uncertainty.

In Kedroff the property right in dispute was the use and possession of St. Nicholas Cathedral in New York City. The Cathedral, since 1905 the seat of the Russian Orthodox Archbishop of the Diocese of North America, had been built partly with money donated by the Orthodox Church in Russia. The rival claimants were the Orthodox Church in Russia (Russian Church) and the Russian Orthodox Church in America (American Church), which claimed to be an autonomous branch, administratively independent of the Russian church. The Cathedral became the focus of the quarrel between the two church groups in 1945, when the St. Nicholas Cathedral Corporation, controlled by the American Church, sued the representative of the Russian Church in ejectment. The plaintiff corporation had held title ${ }^{44}$ to the Cathedral since 1925 but had been out of possession since that time. The defendants, however, had only gained

that the decision of the church had been arrived at legally and fairly. See also IVilliams v. Jones, 258 Ala. 59, 61 So. 2d 101 (1952) ; Knauss v. Seventh-Day Adventist Ass'n, 117 Colo. 541, 190 P.2d 590 (1948) ; Independent Methodist Episcopal Church v. Davis, 137 Conn. 1, 74 A.2d 203 (1950) ; First Free Will Baptist Church of Blounstown v. Franklin, 148 Fla. 277, 4 So. $2 d .390$ (1941) ; Church of God of Decatur v. Finney, 344 Ill. App. 598, 101 N.E.2d 856 (1951) ; Turbeville v. Morris, 203 S.C. 287, 26 S.E2d 821 (1943) ; Hoffman v. Tieton View Methodist Church, 33 Wash. 2d 716, 207 P.2d 699 (1949). Some states still adhered to a literal reading of Watson v. Jones: Maxwell v. Brougher, 99 Cal. App. 2d 824, 222 P.2d 910 (Dist. Ct. App. 1950) ; Pencader Presbyterian Church v. Gibson, 26 Del. Ch. 375, 22 A.2d 782 (1941); Jenkins v. New Shiloh Baptist Church, 189 MId. 512, 56 A.2d 788 (1947).

43. 344 U.S. 94 (1952).

44. Title to the Cathedral had undergone several rather complicated convolutions since its construction. In the beginning, in 1899, title resided in Evdokim, the first Archbishop. In 1905, Evdokim transferred title to a corporation formed under the laws of New York, the trustees of which were the Russian Ambassador, Cassini, and the New York Consul-General, Oustinoff. This corporation held title until 1916, when they returned it to Evdokim once again. In 1917, Evdokim left for Russia and returned the title to the Corporation (Oustinoff and Cassini). In 1925, title was transferred to St. Nicholas Cathedral of the Russian Orthodox Church in North America. This was a new corporation (plauntiff in the action for possession of the Cathedral) whose official head was Platon, the then ruling Bishop of the North American Diocese. Brief for Defendant, pp. 50-51, St. Nicholas Cathedral v. Kreshik, 7 N.Y.2d 191 (1959). 
possession shortly before the action was commenced. At approximately the same time, the New York legislature added to its Religious Corporations Law article 5-C, which declared that all New York churches of the Russian Orthodox faith were now under the administration of the American Church. It defined the Russian Church in America, provided for re-incorporation of Russian Orthodox churches, and described the government of and powers and duties of trustees of such churches. ${ }^{45}$ The plaintiff claimed the right to use and possession of the Cathedral by virtue of the statute. The defendants argued that the statute violated the first and fourteenth amendments, because it denied the Russian Church freedom of exercise of religion by refusing its appointee the use and possession of the Cathedral.

The New York Court of Appeals directed judgment for the American Church, ${ }^{40}$ holding article $5-\mathrm{C}$ constitutional and dispositive of the case. The Cathedral, the court said, was within the purview of the statute, and under it the trustees of the St. Nicholas Cathedral Corporation were bound to administer the property under the laws of the Russian Church in America. The court maintained:

the primary purpose of the Religious Corporations Law is to provide for an orderly method for the administration of the property and temporalities dedicated to the use of religious groups and to preserve them from exploitation by those who might divert them from the true beneficiaries of the trust. ${ }^{47}$

The court went on to hold that the legislature, to effect this purpose, was free to intervene when the "accustomed beneficiaries of religious properties are ... threatened with their loss. ..."48 The accustomed beneficiaries were so threatened because, as the legislature had found, "the Moscow Patriarchate was no longer capable of functioning as a true religious body, but had become a tool of the Soviet Government primarily designed to implement its foreign policy." 49 The legislature, said the court, had therefore found that the American Church rather than the Russian Church "may be relied upon to carry out more effectively and faithfully the purposes of this religious trust." analogized the situation to that in American Communications Ass $n$ v. Douds. Chief Justice Conway read Douds as upholding the non-Communist oath provision in the National Labor Relations Act:

not because any such oath requirement was generally within the power of Congress, but because the specific evil, the existence of which Congress was assumed to have reasonably found as a fact, was such that some infringement upon traditional liberties was justifiable. The case illustrates well that enactments which might seem unconstitutional on their face may

45. N.Y. Religrous CoRp. LAW art. 5-C, §§ 105-08 (1952).

46. St. Nicholas Cathedral v. Kedroff, 302 N.Y. 1, 96 N.E.2d 56 (1950).

47. Id. at 29,96 N.E.2d at 72 .

48. Id. at 30, 96 N.E.2d at 72 .

49. Id. at 32,96 N.E.2d at 74 .

50. Id. at 30,96 N.E.2d at 72 .

51. 339 U.S. 382 (1950). 
yet be sustained if the factual background found by the legislative body warranted an extended exercise of its powers. ${ }^{52}$

Thus the New York statute was held constitutional because any possible infringement of religious freedom was thought to be indirect and justified by a substantial state interest. In its holding, therefore, the Court of Appeals did not see the need for determining whether the American Church had in fact gained its autonomy, or whether the Russian Church could function freely under the Soviet Government, but simply accepted the conclusions of the legislature. ${ }^{53}$

The Supreme Court reversed, 54 and held that Benjamin, the bishop appointed by the Russian Church, was entitled to possession of the property. The Court concluded, through Mr. Justice Reed, that the New York statute

undertook by its terms to transfer the control of the New York churches of the Russian Orthodox religion from the central governing hierarchy of the Russian Orthodox Church ... to the governing authorities of the Russian church in America .... Such a law violates the Fourteenth Amendment. It prohibits in this country the free exercise of religion. ${ }^{65}$

The Supreme Court thought that the New York court's reliance on Douds was unsound. Mr. Justice Reed characterized New York's statute as :

by fiat [displacing] . . . one church administrator with another. It passes the control of matters strictly ecclesiastical from one church authority to another. It thus intrudes for the benefit of one segment of a church the powwer of the state into the forbidden area of religious freedom contrary to the principles of the First Amendment. Such prohibition differs from the restriction of a right to deal with Government allowed in Douds, in that the Union in the Douds case had no such constitutionally protected right. New York's Article 5-C directly prohibits the free exercise of an ecclesiastical right, the Church's choice of its hierarchy. .0

Underlying this reasoning is an assumption exactly opposite to that of the New York court. The Supreme Court assumed that the right to prescribe the use of the New York churches lay with the Russian Church. This assumption allowed the court to categorize the New York Legislature's action as a displacement of one church administration with another. It is true that the New York Legislature's action was intended to vest control of church property in

52. 302 N.Y. at 31,96 N.E.2d at 73.

53. "Whether we, as judges would have reached the same conclusion is immaterial. It is sufficient that the Legislature reached it, after full consideration of all the facts." Id. at 33, 96 N.E.2d at 74.

54. Kedroff v. St. Nicholas Cathedral, 344 U.S. 94 (1952).

55. Id. at 107 .

56. Id. at 119. This interpretation of the Douds case neglects to mention that Chief Justice Vinson, the author of the opinion, admitted that

by exerting pressure on unions to deny office to Communists ... [the provision making the non-Communist affidavit applicable] has the . . . effect of discouraging the exercise of political rights protected by the First Amendment. Men who hold union offices often have little choice but to renounce Communism or give up their offices.

339 U.S. at 393. 
the American Church, whether or not the Russian Church had a claim of right. ${ }^{57}$ Whether Article 5-C did in fact transfer control of the church property, however, depends upon who had the right to prescribe use of the property, before the legislative action. If this right already resided in the American Church, the New York statute did nothing but recognize this fact, no matter what the intent of the legislature was. Under these circumstances, striking down the statute would not be sufficient to decide the case.

The holding that the "transfer" violated religious freedom in that it interfered with the right of the church to appoint clergy is irrelevant. Both the American and Russian Churches could, and did, appoint bishops. The question was who had the right to appoint the bishop of St. Nicholas Cathedral. The answer to this question inescapably involves locating the right to control use of that property. The Supreme Court did make a reference to this underlying issue, but it did so without sufficient discussion:

The record before us shows no schism over faith or doctrine between the Russian Church in America and the Russian Orthodox Church. It shows administrative control of the North American Diocese by the Supreme Church Authority of the Russian Orthodox Church, including the appointment of the ruling hierarchy in North America from the foundation of the diocese until the Russian Revolution. We find nothing that indicates a relinquishment of this power by the Russian Orthodox Church. ${ }^{68}$

This finding is the cornerstone of the opinion. However, the considerations which compelled the finding are not clear. Both sides had introduced voluminous evidence justifying their conflicting claims to control over the Cathedral. Rather than evaluating the evidence to resolve the factual issues, the Court simply assumed that the Russian Church had the right to control use of the property. This assumption led to the characterization of the New York statute as an unconstitutional transfer of control of property. Rather than resting the opinion on these grounds, Mr. Justice Reed added another constitutional dimension to the case by attacking the statutory "transfer" as a violation of the rule of separation between church and state. Mr. Justice Reed pointed out that the Watson $v$. Jones principle - that the civil courts must defer to the church authorities on ecclesiastical matters - was based on the value placed on separation of church and state in American political thought. Admitting that $\mathrm{Wat}$ son v. Jones was not a constitutional decision, Mr. Justice Reed continued:

The opinion radiates, however, a spirit of freedom for religiots organizations, an independence from secular control or manipulation - in short, power to decide for themselves, free from state interference, matters of

57. Article 5-C of New York's Religious Corporations Law provides that churches established before or after the foundation of the metropolitan district, and which had been established under the administration of either the mission (1793-1870), dioceses (18701924) or the district (1924-present) were subject to the law. This obviously includes all churches established by the Russian Orthodox Church, regardless of whatever claim its hierarchy had of jurisdiction. N.Y. ReLrGious CoRp. LAw art. 5-C, $\$ \$ 105-07$. See also 302 N.Y. at $26-27,96$ N.E.2d at $69-71$.

58. 344 U.S. at 120. 
church government as well as those of faith and doctrine. Freedom to select the clergy, where no improper methods of choice are proven, we think, must now be said to have federal constitutional protection as a part of the free exercise of religion against state interference. ${ }^{50}$

This part of the opinion, various commentators have argued, raises Watson $v$. Jones to constitutional status. ${ }^{60}$ If this is so, the case represents a significant constitutional extension, since it would make the first amendment guarantees applicable to religious organizations as well as to individuals. Mr. Justice Reed's reasoning, however, is hardly adequate to support such an extension. His argument that religious organizations have a constitutional right to appoint clergy obscures the basic issue in all church property disputes - the determination of the right to control use of the property. In Kedroff both sides were admittedly free to appoint clergy, and in fact did so. ${ }^{01}$

On remand, the New York Court of Appeals directed a new trial on the issue of whether the Russian Church could function as anything except an arm or agent of an anti-religious civil government, so that its appointees would not be the proper trustees to administer the church property. ${ }^{62}$ After hearing more evidence, the New York Supreme Court found that the Russian Church was a functioning religious order and that the Cathedral was under its control. ${ }^{63}$ The Court of Appeals reversed once more, 64 using a common law implied trust doctrine - that a court in the exercise of its discretion could replace trustees who could not be relied upon to carry out the purposes of the trust. The Cathedral "was subject to the implied trust that it must be used and employed ac-

59. Id, at 116 .

60. See Pfeffer, Church, State and Freedon 250 (1953); Mark de Wolfe Howe, The Juridical Status of Churches, I Conference Procendngs, The Institute of Ciruncn and State 6, 16 (Villanova University 1958); Howe, Forz'ard: Political Tilsory and the Nature of Liberty, The Supreme Court, 1952 Tcrm, 67 HaRv. L. REv. 91, 92-95 (1953); Duesenberg, Jurisdiction of Civil Courts Oucr Religious Issues, 20 Onto Sr. L.J. 508. 522-28 (1959).

61. Mr. Justice Frankfurter saw the difficulty in this line of reasoning, and sought to characterize the dispute as a struggle for "power to exercise religious authority." He pointed out that "St. Nicholas Cathedral is not just a piece of real estatc . . . . [but] the seat and center of ecclesiastical authority." 344 U.S. at 121. In his view, courts, not legislatures, were alone empowered to settle these disputes "in strict subordination to the ceclesiastical law of a particular church prior to a schism." Id. at 122. However, instead of making a determination of the "ecclesiastical law" involved, AIr. Justice Frankfurter simply assumed administrative power to reside in the Russian Church:

Both parties to the present controversy agree that the present Patriarch is the legitimately chosen holder of his office, and ... [he is acknowledged] ... by his coequals in the Eastern Confession, the Patriarchs of Constantinople, Alexandria, Antioch, and Jerusalem, and by religious leaders throughout the world, including Id. at 125. the present Archbishop of York.

62. 306 N.Y. at 38,114 N.E.2d at 197.

63. St. Nicholas Cathedral v. Kreshik, 9 Misc. 2d 1069, 166 N.Y.S.2d 245 (Sup. Ct. 1957), aff'd memn., 6 App. Div. 2d 866 (1958).

64. St. Nicholas Cathedral v. Kreshik, 7 N.Y.2d 191, 164 N.E.2d 687 (1959). 
cording to the discipline, rules and usage of the Russian Orthodox denomination and for the benefit of the members of its North American Diocese."0t Waison $v$. Jones was said to have a basic qualification that "The court must always be careful to ascertain whether the central church authority really exists or enjoys sufficient freedom of action to be able to function as such." The court found that "the Moscow Patriarchate enjoys at best a nominal and conditional existence, at the sufferance of the Communist rulers of the Soviet State. . . "'67 The Russian Church was therefore held to be an unfit trustee. Finally, the court argued that to award the Cathedral to the Moscow appointec would involve a "violation of the constitutional protection against State [Russian] interference in the free exercise of religion." 08 This neat twist, as well as the common-law doctrine, failed to impress the Supreme Court. In St. Nicholas Cathedral v. Kreshik, ${ }^{69}$ the Court again reversed the New York Court of Appeals in a memorandum opinion, citing Shelley $v$. Kraemer ${ }^{70}$ for the proposition that the court could not do what the legislature had been forbidden to do. The decision of the New York courts, the Court stated, rested on the same premises as the statute struck down in Kedroff - that the appointee of a Communist-dominated church could not validly exercise his authority under the common law of New York.

The basic flaw in the New York Court of Appeals' second opinion was that it failed to recognize the importance of the Supreme Court's assumption that the right to determine use of the Cathedral lay in the Russian Church. Thus, on remand from the Supreme Court, the Court of Appeals did not pretend to settle the question of control of property as such, but awarded the property to the American Church solely on the grounds that the Russian Church was an improper trustee. Had the New York court rested its decision on a finding of which party had the right to determine use, the Supreme Court might have been obliged to announce its own criteria for court determination of this crucial issue. As it is, Kreshik may simply stand for the proposition that Communist taint is no bar to control of church property.

The most surprising aspect of the Supreme Court decisions in Kedroff and Kreshik was the use of first amendment language, which appears to be unnecessary to reach the Court's conclusions. If the Court's finding that the Russian Church had never relinquished administrative control over the American Church is to be taken seriously, it should have been dispositive of the case. Under Watson $v$. Jones, if the Russian Church were found to have the right to prescribe use of church property, the Court was bound to enforce that right. Nor was the first amendment language in Kedroff necessary to invalidate the statute, since if there had been a transfer, New York's action would have been

65. Id. at 205, 164 N.E.2d at 694.

66. Id. at 216,164 N.E.2d at 700 .

67. Id. at 214,164 N.E.2d at 699 .

68. Id. at 217,164 N.E.2d at 700.

69. 363 U.S. 190 (1960).

70. 334 U.S. 1 (1948). 
an unconstitutional taking, in the absence of compensation and a finding of public purpose. The first amendment language was also unnecessary to justify the Kreshik opinion, since the fourteenth amendment obviously bars a court as well as a legislature from accomplishing an unconstitutional taking. Under Reed's assumption of ownership the only possible relevance of the first amendment language would lie in the fact that the injured party was a church. ${ }^{71}$ The crucial constitutional clause should not have been the free exercise clause but the due process clause.

The New York court's reading of the statute might raise a real first amendment issue if the implied trust theory were accepted as a valid characterization of church methods of property control. The legislature, according to Judge Conway, exercised its power over the appointment of New York trustees and disqualified the Russian Church hierarchy on the grounds of Communist taint. Such an action probably would be constitutional if a mere private trust were involved ${ }^{72}$ although in a case involving a religious trust there probably must be a showing of "clear and present danger" to permit any state interference on political grounds. ${ }^{73}$ In any case, since the Court did not accept the characterization of the New York court that the members of the church hierarchy were trustees, this theory cannot support the first amendment language.

The Court could also have been saying in Kedroff that the New York Legislature had no power to determine the ownership of religious property because the first amendment bars the state from taking any part in religious disputes. ${ }^{74}$ Under this theory any decision in this area involves, to some extent, both an establishment of the religion of the winner and an interference with the free exercise of the loser. This reading would account for the first amendment language in Kedroff. The reference to Shelly $v$. Kraemer in Kreshik could then be taken to mean that involvement in religious disputes is forbidden to courts, as well as to legislatures. If followed to its logical conclusion, however, this argument would bar any court, including the Supreme Court, from deciding the case. The finding of Russian administrative authority may have been the Court's way of restoring the status quo before New York's action, but in restoring the status quo, the Supreme Court necessarily made a finding that the Russian Church was entitled to the use of the Cathedral. Applying the same logic used to bar New York court action, the Supreme Court must have

71. The same reasoning would hold that the robbery of a pricst or minister violated his rights to freedom of exercise of religion as well as the laws against theft.

72. See Carrier v. Carrier, 226 N.Y. 114, 123 N.E. 135 (1919); 1 Scorr, Trusts $\S 107$ (2d ed. 1956), 4 id. § 387.

73. There is a hint of this in the majority opinion, 344 U.S. at 109-10; cf. Cantwell v. Connecticut, 310 U.S. 296, 308 (1940).

74. Mr. Justice Brennan has cited both Kedroff and Kreshils as reaffirming Waison v. Jones to the extent

that in order to give effect to the First Amendment's purpose of requiring on the part of all organs of government a strict neutrality toward theological questions, courts should not undertake to decide these questions.

School Dist. v. Schempp, 374 U.S. 203, 243 (1963). 
violated the freedom of exercise of the American Church and established the Russian Church. Another flaw in the logic underlying this theory might be illustrated by imagining that the New York courts had refused to hear the original suit. This refusal to act could be viewed as establishing the Russian Church, whose appointees were in possession, and interfering with the freedom of exercise of the members of the American Church. The persuasiveness of this example can be heightened by hypothesizing that the party happening to be in possession had no claim under any other theory to determine right of use of the property.

Further, a constitutional doctrine prohibiting courts from settling religious property disputes would have serious practical consequences. The state has a legitimate interest in keeping title and ownership in land settled and secure. This "housekeeping" interest requires that the state know at all times the owners of property within its borders, so that injured persons may find responsible owners, and so that property may be freely alienable. The state also has an interest in affording to disputants some recourse other than the sword for settling their arguments, and the state alone has the authority to make and enforce judgments between such disputants. If only from a practical point of view, then, the first amendment should not be an absolute bar to a court's tak:ing jurisdiction of a church property dispute.

Under any reasonable reading of the Kedroff and Kreshik opinions, then, the Court's use of the first amendment language after it had assumed control over the property to lie in the Russian Church was superfluous. The critical determination in Kedroff, as it was in Master, was that of the right to prescribe the use of the property. This is not to say that the first amendment has no bearing on church property disputes. In fact, the Supreme Court's assumption of control by the Russian Church obscured the actual first amendment issues in the case. The first amendment is relevant in the beginning - in determining the right to prescribe use of church property - not after that determination has been made or assumed. For this reason, the various possible rules for determining control over church property must be tested in the light of first amendment limitations. Basically, the state can choose either of two main avenues of approach to these church property problems: it can set up more or less arbitrary rules of its own, declaring where, for the state's limited purposes, control will be said to lie, or it can look to the individual church's property rules and accommodate state law to these rules.

If the state imposes its own rules, it might adopt what could be called the "formal title" doctrine - whoever holds title to the property has the riglit to determine the use of the property. ${ }^{75}$ Initially, the state would require the

75. Civil courts have on occasion approximated this approach. See Evangelical Lutheran Synod v. First English Lutheran Church, 47 F. Supp. 954 (W.D. Okla. 1942), rev'd, 135 F.2d 701 (10th Cir.), cert. denied, 320 U.S. 757 (1943). In that case the congregation of the First English Lutheran Church had voted to secede from the Kansas Synod and align itself with the Midwest Synod, similar in religion but different in administrative respects. The Kansas Synod attempted to bar the secession, and both Synods 
churches to designate a title-holder or group of title-holders for the church property. The "formal title" approach would treat title-holders as owners in fee simple rather than as trustees, and would ignore any restrictions placed upon them by the church organization. The sole role of the state courts would be finding the locus of formal title. The state would thus leave maintenance of internal discipline entirely to the church. Application of this theory in Kedroff would have resulted in victory for the American Church, who happened to have formal title at the time of the suit.

The virtue of the "formal title" policy lies solely in its simplicity. This method places so much power in the hands of the title-holder that it is an invitation to anarchy within the church government. Further, it involves a refusal to enforce firmly established equitable principles. A member who donates money or property to his church clearly does not intend that it be subject to the unfettered whim of the person who happens to have title to church property. The inequitable results which could follow from the "formal title" theory would seem to outweigh any advantages it may have from a purely administrative standpoint.

Another possible state-imposed rule would be proportional division of church property in case of dispute. This theory would be based on the idea that each member of a church possesses a certain equity in all church property throughout the world. Although it may seem absurd to force a church to buy off several disgruntled members, the appeal of this theory increases as the number of church members in each quarreling faction increases. It might seem reasunable to allow a substantial minority some compensation for the loss of its customary use of church property. This proportional division theory, however, would be almost impossible to implement. ${ }^{78}$ The court would first have to decide whether a disgruntled party was in fact a member of the church, and then would have to tackle the problem of evaluating his share in the church property. ${ }^{77}$ Even if either of these determinations were feasible, such a rule

appealed to the Lutheran High Commission. The Commission did not expressly adjudicate the matter but volunteered the opinion that the "general exercise of [the right to withdraw from a Synod and join another] should be discouraged as destructive of sound church government of the United Lutheran Church in America." $47 \mathrm{~F}$. Supp. at 958. The court of appeals held that the Kansas Synod had no property interest in the church because the title, and therefore ownership, of the property resided in the church corporatiun. $135 \mathrm{~F} .2 \mathrm{~d}$ at 703 . Carried to its logical limits, this decision would alluw the curporation authorities to make any decisions concerning property use. Also see Banacum v. MLurphy, 71 Neb. 463, 104 N.W. 180 (1905).

76. Kentucky has a statute which seems on its face to prescribe a similar solution, allowing each party in a church dispute to use the church property for worship a part of the time "proportional to the members of each party." Kx. REv. STAт. \$273.120 (1960). However, this statute has been limited by the courts to apply only for such time as required for the proper ecclesiastical authority to determine which faction is entitled to the property in question. Jones v. Johnson, $295 \mathrm{Ky} .707 .175$ S.W.2d 370 (1943); Thomas v. Lewis, 224 Ky. 307, 6 S.W.2d 255 (1928).

77. A related idea would have a court determine ownership by the source of funds used to build and maintain a church. Such a determination is similar to a finding of the 
would probably lead to the multiplication of church quarrels, and an enormous increase in the number of these quarrels reaching the civil courts.

Finally, the state could impose a polity upon a church. Both Maine and Massachusetts, for example, have constitutional provisions that each congregation shall have the power to elect its own pastor. ${ }^{78}$ These effectively give property control to the congregation, since selection of clergy for a given benefice is tantamount to allocating the right to prescribe use of church property. ${ }^{70}$ However, in imposing a congregational model, the court would have to decide just who the members of the congregation really are. The court might apply its own rules to determine congregational membership, a process which wotild lead into even murkier waters than would an attempt to determine an individual's equity in church property. Alternatively, it could look to the church rules for membership. In a hierarchical church, the church authorities will ustually have the power to determine membership; thus the court will often be in the anomalous position of looking to the hierarchy for membership rules and to the congregation in order to determine whether that body will follow the hierarchy's property rules.

There are constitutional objections to each of the above schemes. An integral part of any religion is its form of government. Essential to any church government is the power to administer church property. If the state imposes a uniform system of religious land tenure, this imposition is a state establishment of a power structure within the religious government. 80 Such an establishment is analogous to a state's imposition of a certain form of prayer on people of all faiths, an act found unconstitutional in Engel $v$. Vitale. 81 The imposition of a particular form of property control on all churches alike is the source of the constitutional infirmity, regardless of how many of the churches happen to use equity of an individual member, but is more sophisticated, since it takes into account the sources of funds outside a congregation. The church, for example, might have been constructed partially with funds from the mother church, as was St. Nicholas Cathedral. Parishes of hierarchical churches, however, frequently both give money to and receive it from their dioceses. Unravelling all of these strands would present an even more difficult task for the courts than determining an individual's equity.

78. ME. Const. art. 1, $\$ 3$ (1954); MASs. Const. $\S 113$, art. xi (1951).

79. In other words there is a difference between appointing a bishop or pastor in vacuo and having the power to appoint a bishop who will occupy a particular church or cathedral.

80. Mr. Justice Frankfurter's concurring opinion in Kedroff makes the point that if the state is allowed to say who will "control the common center of devotion," it will afford the winner religious power through the use and occupancy of such church property. 344 U.S. at 122-23. However, Mr. Justice Frankfurter's position is also open to question. The purely factual observation can be made that St.Nicholas Cathedral had been in possession of John Kedroff and his family for twenty years prior to the lawsuit. Kedroff and his sons were members of neither the American or Russian Church, but the "Living," or "Renovated" church, which had gone out of existence shortly after its formation. The Kedroffs had gained no power to govern either the American or Russian Church. Thus the state's determination of property control is not necessarily decisive in church government struggles.

81. 370 U.S. 421 (1962). 
similar forms of property control. In essence, the state is making rules for the religious government of the church, a clear violation of the establishment principle. Further, state-imposed rules raise grave questions of freedom of exercise of religion. When a state imposes on the church a different form of control over land from that consented to by the church member, it is impinging on his freedom of exercise of religion. Also, if the church itself is considered to be vested with constitutional rights, ${ }^{82}$ as was suggested in Kedroff, then $a$ fortiori the church's freedom of exercise has been curtailed as well. Unlike the establishment argument, however, the free exercise argument applies only when the state-imposed system differs from that of the church.

The constitutional objections may be lessened if the state takes the second avenue of approach, that of looking to the church's own rules. If the state does not arbitrarily impose a uniform system of land tenure on all churches, it must necessarily find rules for property control within the existing structure of the church government. In its search for these rules, courts should avoid entanglement in concepts such as "title" and "ownership." Actual title is usually relatively unimportant to a church; ownership may consist of many separate interests. The property rights which are significant are the rights of appointment of hierarchy and clergy to given benefices, the right to determine membership in the congregation, and the right to administer the church finances and prescribe discipline. It is unprofitable to characterize "ownership" or "title" as the grail for which the courts are to search. "Control," "power to adjudicate," or "power to prescribe use" seem more useful ways of saying the same thing.

A middle ground between state imposition of uniform church property rules and an attempt to apply the church's own rules would be the trust theory: the church property is impressed with a trust for the use and benefit of the church members. Under the English form ${ }^{83}$ of this trust theory the church members are defined as those who adhere to the faith of the founding fathers, because it is assumed that the donors of the church property intended that it be used by the church as it existed at the time of the donation. Thus the English courts in the event of a church property dispute examine the contentions of each side to determine which represents the faith of the founders. This approach has the advantage of reaching the actual issues of the dispute rather than applying some artificial state rule, but the court may not be the most competent body to decide the complicated issues of an ecclesiastical quarrel, especially if the dispute involves arcane theology. ${ }^{84}$ The application of the English rule also stifles natural development of church doctrine. Further, the rule rests upon the questionable premise that the donors of church property intended that the

82. See text accompanying note 60 supra. Also see Howe, Foreward: Political Theory and the Nature of Liberty, The Supreme Court, 1952 Term, 67 HAnv. L. REv. 91, 92-95 (1953). See also address of Mark de Wolfe Howe, The Juridical Slatus of Churclics, I Conference Proceedings, The Institute or Church and State 6 (Villanova University 1958).

83. See text at notes 10-14 supra.

84. See Free Church of Scotland v. Overtoun, [1904] A.C. 515 (Scot.). 
church remain static, and thus imagines that the donors attached strings to their gift which prevent the church from ever exercising full dominion over its property.

The trust theory can be modified to avoid some of the drawbacks of the English version. Rather than assuming that the intent of the donor was to give to a body which would adhere strictly to the faith of the founders, it is more plausible to recognize that the donor foresaw the possibility of change. Thus in applying the modified trust doctrine the courts would assume that actions of the church authorities were valid unless plainly ultra vires. Though this theory makes possible some evolution in the church doctrine, it still involves the court in the determination of whether the church body making the change was competent to do so. For instance, the court might have to decide whether a given rule or doctrine was so fundamental to the church that no church authority could change it, or it might have to decide the even more difficult question of whether there actually had been a change. In addition, this modification does not overcome the basic difficulty with the trust theory - that it assumes, probably contrary to fact, that the donor of church property has not made a complete gift but has retained some strings over the church property. Even if this assumption is valid, there remains the policy question of whether gifts to churches should be regarded as incomplete in the absence of provisions so stating. Final$1 y$, in those cases where the implied trust is a court-created fiction - where the original donor did not so condition his gift - application of either of the trust theories represents an imposition of a state- created rule of land tenure, and a disregard for the decision of the church authorities, who govern by the consent of the members.

Both trust theories also contain constitutional infirmities. Application of the English trust theory clearly represents an establishment since it requires the court to examine the beliefs of the rival claimants and to choose between them on the basis of an implied - and often fictional - trust. The choice of the court represents state sanction of a particular doctrine and therefore establishes the religion of the winner. The modified trust theory establishes a religion in the same way, since the court must again investigate the doctrines of the church to decide which are fundamental and hence beyond change. On the other side of the coin, both trust doctrines deprive both the church as a whole and its individual members of the freedom to exercise their religion, since use of particular church property is often connected with religious practice. Conditioning the right to use property on adherence to certain religiots beliefs restricts grievously the rights of the individual members to worship as they please, and the right inherent in a church to grow and change. ${ }^{85}$

A second theory assumes that gifts to churches are complete and that property control lies somewhere in the governing body of the church. The members of the church are assumed to have given their consent to be governed by

85. See McGregor, Church and State, Associations and Corporate Personality, 61 S. Afr. L.J. 133 (1944). Compare arguments by Haldane, K.C. in Free Church of Scotland v. Overtoun, [1904] A.C. at 608-11 (Scot.). 
the church's own rules, as interpreted by the church authorities. This is the underlying theory of Watson v. Jones, which, to be sure, embodies a most expansive reading of the members consent. As the cases modifying Watson v. Jones illustrate, however, it is unreasonable to assume that a member consented to have the church rules interpreted unfairly or arbitrarily by the church authorities. ${ }^{86}$ A doctrine of review based on these considerations would allow the church authorities to interpret the church laws, usage, doctrine and jurisdiction. The function of the civil court would be limited to determining whether the action of the church tribunal was patently unfair or on its face violated the church's laws. This approach presupposes that the church tribunal with the power to prescribe use of the property has been identified. It thus would solve disputes similar to Watson $v$. Jones, where both parties recognize a single church tribunal as having the power to control property. In situations like Kedroff, however, where there are two rival factions, each claiming the right of control over the property, the court must choose between them before it can proceed to test the decision of the proper tribunal against the principles derived from Watson v. Jones. Choosing between rival factions can be most difficult, but there are guidelines available. As Master ${ }^{87}$ illustrates, the court should go back and find a time when the control of the property was undisputed. Proceeding from there, the court can inquire whether the undisputed control over the property had ever been surrendered or lost, either by cession of the property to another group, or by relinquishment of control over the property under the principle of laches or estoppel.

The latter principle has been demonstrated in a state court, ${ }^{89}$ after the Supreme Court decision in Kreshik. A dispute similar to the Kedroff situation developed involving a quarrel between the American Church and the Russian Church over the use and possession of St. Peter and St. Paul Church in Lorain, Ohio. The church had been under Russian leadership until 1925, when it joined the American Church. In 1957 the church engaged George Burdikoff as pastor. After he had been installed, he announced that he had switched his allegiance to the Russian Church. The Ohio Court of Appeals held that Burdikoff did not have the right of possession. The rationale was that the Russian Church was barred from asserting the right to prescribe use, since it had not asserted its right to control in the intervening 32 years, during which time the parish had adhered to the American Church. This case, and Master, illustrate the complexity of the issues involved in the initial determination of the right to control

86. Of course, these rules must be interpreted within the context of church law, which might itself contain elements which seem unfair or arbitrary to a layman. However, a member can have no complaint if he is dealt with in accordance with church law extant at the time be joined the church. Presumably his consent to be governed includes this body of laws.

87. Master v. Second Parish of Portland, 124 F2d 622 (1st Cir. 1941).

88. Russian Orthodox Greek Catholic St. Peter and St. Paul's Church v. Burdikoff, 117 Ohio App. 1, 189 N.E.2d 451 (1962). 
use of church property. But they also give grounds for hope that the courts can evolve workable standards when they recognize the problem.

Yet even the policy of state deference to church decisions involves constitutional problems. The establishment clause can be read to prohibit state aid to any or all religions. ${ }^{80}$ By enforcing church decisions, the argument wotld go, the state is establishing the religion of those whose decisions it enforces. This extreme disestablishment position would only be satisfied by denying the state the right to help churches in any way. The logical consequences of this theory would require the refusal by a state to adjudicate boundary disputes between a church and its neighbors, or even to extinguish fires on church property. These examples show the discriminatory and impractical nature of this reading of the establishment clause. Moreover, it might be argued that a court by denying its jurisdiction over church disputes would, in effect, be establishing the religion of the ultimate winner of the contest..$^{90}$

A more moderate reading of the establishment clause would maintain that the state must remain strictly neutral, neither aiding nor hindering any or all religions. ${ }^{91}$ Under this position all rules by which churches are treated differently from other non-profit voluntary organizations are subject to criticism. By this yardstick, the strict Watson v. Jones rule with its complete deference to church authorities is objectionable since other non-profit voluntary organizations are not absolutely immune from state imposed standards. On the other hand, the doctrine which would have the courts look more closely to fairness and good faith criteria seems to correspond more closely with the rtiles governing other voluntary associations. ${ }^{.2}$

The rule of Watson $v$. Jones as modified by subsequent case law also affords the maxim freedom of exercise to individual members of a church. As Mr. Justice Miller emphasized, the power of the churches to govern is derived from

89. One of the classic definitions of the establishment clause was embodicd in a dictum by Mr. Justice Black, speaking for the Court in Everson v. Board of Educ., 330 U.S. 1 (1947).

Neither a state nor the Federal Government can set up a church. Neither can pass laws which aid one religion, aid all religions, or prefer one religion over another.... Neither a state nor the Federal Government can, openly or secretly, participate in the affairs of any religious organizations or grouns and vice versa. Id. at 15, 16.

See also the dissent by Mr. Justice Frankfurter, Board of Educ. v. Barnette, 319 U.S. 624, 646 (1943) ; dissent of Mr. Justice Rutledge in Everson v. Board of Edtuc., 330 U.S. 1, 28 (1947); Pfeffer, Churce, State ANd Freedors 62 et passim (1953).

90. The logical extension of this line of reasoning culminates in the argument that by insuring the religious liberty of churches, the government has given aid to religions, thus violating the establishment principle. See HowE, op. cir. sttpra note 82 at 22-23.

91. See concurring opinion of Mr. Justice Brennan in School Dist. v. Schempp, 374 U.S. 203, 230 (1963).

92. See generally Chafee, The Internal Affairs of Associations Not for Profit, 43 Harv. I. REv. 993 (1930); Developments in the Law, Judicial Control of Actions of Private Associations, 76 HARv. L. REv. 983 (1963). 
the consent of the members, who agree to be governed by the church rules.93 If the state defers to the decisions of church authorities made in accordance with these rules, the state is merely enforcing the original consent of the member, and thus cannot be accused of depriving him of the freedom to excrcise his religion. If the church as a whole can claim a constitutional right to freedom of exercise, it must be derived from the members through the aggregate of their consent. Therefore the church can only claim the protection of the freedom of exercise clause so long as its decisions are made within the framework of its own rules. It is easy to imagine a case in which the church itself by mismanagement, fraud or bad faith interferes with the free exercise of religion by certain of its own members. Wrongful expulsion would be one example. The fact that there can be a direct clash between the church and a member, both claiming protection under the freedom of exercise clause, indicates that the power of the churches should be limited to the quantum of consent given it by its members. Since Watson $v$. Jones, as modified by the later case law, should be read to impose only these limits, it does not impinge on the freedom of exercise of the church or of its individual members.

This examination of the possible theories designed to identify the church tribunal with the power to control property reveals the basic dilemma inherent in Kedroff. The Court in that case failed to realize that no matter what methods are used to settle church property disputes, each one will be subject to first amendment attack. Even Watson $v$. Jones, the case purportedly raised to constitutional status, can be challenged as an establishment of religion.

Placed in this position, the courts must seek a solution which avoids as far as possible the strictures of both the establishment clause and the free exercise clause, which protects the church from arbitrary action by the state and the individual members from arbitrary action by the church, and which accommodates the state "housekeeping" interests yet respects the many different forms by which different churches hold and control their property. This task is made more difficult by the various and sometimes conflicting interpretations of the establishment clause. If the establishment clause is looked upon as creating an absolute wall between church and state, then all of the possible rules are subject to criticism, because each involves the state to some extent in church affairs. The "formal title" rule is perhaps least objectionable from this point of viev, since the state need not deal with either the theology or the administrative rules of the church, but looks solely to the locus of title. However, the "formal title" doctrine creates an establishment from another point of view, since it establishes the religion of the title-holder. The most objectionable rule from an "absolute wall" point of view is strict adherence to Watson $\nu$. Jones. This rule gives the church plenary power over church property and allows the church to use the courts to enforce its decrees. Between these two extremes lies an area in which

93. 80 U.S. (13 Wall.) at 729. The church may, on the other hand, maintain that its authority is a delegation of Divine Authority. However, the state cannot recognize Divine Authority without violating the establishment principle. See School Dist. v. Schempp, 374 U.S. 203, 214-22 (1963). 
the courts test the church action to see that it meets some requirements of fairness and good faith. The difficulty here is that as the court avoids blind and unquestioning establishment of church decrees, it drifts toward an equally obnoxious alternative - that of deciding theological questions. Indeed, by continuing the process of choosing different interpretations of the establishment clause, each theory advanced can be tarred with the first amendment brush.

A court could deal with the dilemma created by the various readings of the establishment clause by treating it as of secondary importance. The court would then ground its choice of method primarily within the framework of the free exercise clause. Significantly, only the Watson v. Jones principles as modified by later case law are wholly compatible with the free exercise clause. All of the other tests conflict to greater or lesser extent with the free exercise of religion. Of these other tests, the modified trust theory is least objectionable; but it still may result in a court's restricting the ability of a church and its members to adopt new doctrines or beliefs. Strengthening the conclusion derived from the free exercise standpoint is the fact that the test derived from Watson $v$. Joncs has a long history of relatively successful application. The test does not involve the courts to any significant extent with theological disputes, and although it may sometimes be difficult to find the body within a church with the power to control property, the case law illustrates that this problem, when recognized, can be solved.94

If the establishment clause is taken into account, the latest interpretation of that clause by the Supreme Court supports the selection of the principles derived from Watson $v$. Jones. Under this reading, ${ }^{05}$ the constitution demands strict neutrality by the state toward all churches. All the tests other than $W a t$ son $v$. Jones as modified erect special rules of decision for church property disputes, while the Watson $v$. Jones formula most closely approximates the gen* eral body of law applicable to all non-profit voluntary associations. Indeed, the only view of the establishment clause which strongly conflicts with the principles derived from Watson v. Jones is the strict separation interpretation the "absolute wall" theory. Yet this is the least acceptable theory of the estab-

94. See Master v. Second Parish of Portland, 124 F.2d 622 (1st Cir. 1944); Romanlan Orthodox Missionary Episcopate v. Trutza, 120 F. Supp. 183 (N.D. Ohio 1952), aff'd, 205 F.2d 107 (6th Cir. 1953) ; Russian Orthodox Greek Catholic St. Peter and St. Paul's Church v. Burdikoff, 117 Ohio App. 1, 189 N.E.2d 451 (1962) (another case which could have been handled more sensibly if the problem had been recognized); Evangelical Lutheran Synod v. First English Lutheran Church, 47 F. Supp. 954 (W.D. Okla. 1942), rev'd, 135 F.2d 701 (10th Cir.), cert. denied, 320 U.S. 757 (1943). In the last case, the highest church tribunal, recognized by both factions, had withheld decision as to whether a congregation could switch allegiance from one Synod to another within the church. The court of appeals held that neither Synod had a property interest in the church property, since title was in the church corporation. A more practical handling of the case would have been to recognize that the highest church body could prescribe the use of the property, but had not done so. In effect, the court of appeals could have remanded the case to the highest church tribunal since it had the power to make a decision binding upon the civil courts.

95. School Dist. v. Schempp, 374 U.S. 203 (1963). 
lishment clause, ${ }^{96}$ and every rule for decision of church property disputes would be suspect under this interpretation.

There is still another interpretation of the establishment clause, which seems most sensible in the context of church property disputes. This view realizes that various interpretations of the establishment clause may conflict with each other, and with the free exercise clause. Therefore, it says, rather than applying each clause in isolation, an attempt should be made to reconcile them, in order to develop a unitary and internally consistent reading of the first amendment. Because the establishment clause can be self-contradictory, the key to a unitary concept of the first amendment is to treat the free exercise clause as paramount, and the establishment clause as primarily a means of safeguarding freedom of exercise. ${ }^{97}$ The test derived from Watson $v$. Jones is even more attractive under this theory. Alone of all the possible tests for resolving church property disputes, it maximizes freedom of exercise for both the church as a whole and its members, and impinges marginally, if at all, on traditional establishment concepts. This method represents a fair solution for both the church and the individual church member, and a workable accommodation between the interests of the state in property within its borders and the interests of the church in administering its property with a minimum of interference.

In retrospect, although the Supreme Court opinion in Kedroff assumed the very issue it purported to decide, its elevation of $W$ atson $v$. Jones to constitutional status served a valuable purpose. It focused attention on the first amendment problems latent in church property disputes, and it forced re-examination of a hundred-year-old doctrine in the light of modern conditions. Although the Kedroff-Kreshik opinions raised more questions than they answered, their choice of the Watson $v$. Jones principles has proved to be correct.

96. Under this theory the establishment and free exercise clauses would always be in opposition, since enforcing a church decision would establish a religion, while refusing to enforce a church decision would establish the religion of the dissenters from that decision. See text accompanying and following note 74 supra.

97. This is not to say that the establishment clause must be ignored. Its application, however, would always be determined with reference to the free exercise clause. The most complete statement of this position is that of Mrr. Justice Stewart, dissenting, in School Dist. v. Schempp, 374 U.S. 203, 308-20 (1963). 